\title{
Modification process in nixtamalization of folic acid-rich dent corn (Zea mays identata) and its identification as smart food fortificant
}

\author{
Agustine Susilowati*, Puspa Dewi Lotulung, Yati Maryati, and Aspiyanto \\ Research Center for Chemistry - Indonesian Institute of Sciences, Kawasan PUSPIPTEK, Serpong 15314, South Tangerang, Banten, \\ Indonesia.
}

\begin{abstract}
A modification on nixtamalization process of dent corn (Zea mays identata) was conducted in order to recover natural folic acid-rich corn. Nixtamalization process on varieties of white dent corn and yellow dent corn subsequently were performed by steeping solution of $\mathrm{Ca}(\mathrm{OH})_{2}$ at concentrations of $0,10,20$ and $30 \%$ (w/w corn dissolved protein) for 18 hours, and boiling at $90{ }^{\circ} \mathrm{C}$ for $15,30,45$ and 60 minutes. Result of research showed that concentration of $\mathrm{Ca}(\mathrm{OH})_{2}$ solution becoming more and more high and long boiling time increased both folic acid and reducing sugar, dropped total solids and total sugar, and fluctuated dissolved protein for both types of corn. Nixtamalization optimalization of white dent corn and yellow dent corn were achieved at combination of $\mathrm{Ca}(\mathrm{OH})_{2} 20 \%$ (w/w corn dissolved protein) for 60 minutes of boiling and $\mathrm{Ca}(\mathrm{OH})_{2}$ $30 \%$ for 30 minutes of boiling and gave folic acid of 466.81 and $506.74 \mu \mathrm{g} / \mathrm{mL}$, respectively. In this condition, it is occurred an increase of folic acid $192.3 \%$ (1.9 folds) and $139.89 \%$ (1.4 folds) when compared to initial material of corn. Identification on folic acid monomer and glutamic acid monomer of both nixtamalized dent corn and yellow dent corn at optimum operation condition displayed domination of folic acid monomer with molecular weight (MW) 442.56 Dalton (Da.) with relative intensity $25.51 \%$, and 441.73 Da. with relative intensity $100 \%$, while glutamic acid monomer of nixtamalized yellow dent corn and nixtamalized white dent corn were dominated by monomer with MWs of $148.27 \mathrm{Da}$. and $148.32 \mathrm{Da}$., and relative intensity 3.73 and $1.8 \%$.
\end{abstract}

\section{Introduction}

Cereal grains have been the staple component of human diet for thousands of years. Corn, wheat and rice together accounted for about $89 \%$ of total cereal production worldwide. Today, cereal grains are still the most important source of calories to the majority of the world population. In developing countries, about $60 \%$ of calories are derived from cereals, whereas in the developed world it is only $30 \%$ [1-3]. Corn (Zea mays identata) is one of the best cereal grains as potential source of polysaccharides to produce energy and to build body, which is supported by functional properties as sufficient high source of protein $(7-9 \%)$. Due to high protein concentration, corn has the most important source of folic acid, in which folic acid is composed by glutamic acid expressed as dissolved protein [4]. In order to achieve corn products as natural source of folic acid for smart food and to diversify a wide variety and attractive products, it can be conducted through nixtamalization process.

Nixtamalization process on corn is generally performed to achieve corn flours with proved protein quality, increase calcium content and better physical properties in application on food products. Nixtamalization using suspension of calcium hydroxide

\footnotetext{
* Corresponding author: agustine_1408@yahoo.co.id
}

will inhibit its occurrence of fractionation of amylose and amylopectin chain, so that they are binding and inhibiting its occurrence of retrogradation (snack products with high crispy level) or inhibiting its occurrence of syneresis (sauce and pudding products). Nixtamalization on corn is a process, in which corn is boiled directly in water solution of $\mathrm{Ca}(\mathrm{OH})_{2}$ without filtering, steeped overnight, and washed and cooled at room temperature $\left(26-28{ }^{\circ} \mathrm{C}\right)$ in order to obtain and improve nixtamal product with better physical property (texture, color, flavor, aroma, taste, shelf life), maintain functional property (minimize loss of folic acid), ease starch gelatinization, increase nutritional value, adsorb water mass, and drain a portion of its skin and pericarp from corn grains $[5,6]$. Nixtamalization process on corn is done to soften corn grain and facilite absorbing $\mathrm{Ca}(\mathrm{OH})_{2}$ so that nixtamalized product undergoing a series of significant changes on the physical and chemical properties (color, aroma), and the morphological and rheological properties of starch will be generated. Softening and swelling on the optimum corn starch gel (65 $-85{ }^{\circ} \mathrm{C}$ ) is able to enlarge volume (22 folds) when compared to corn starch granula at $95^{\circ} \mathrm{C}$. High content of folic acid in corn (kernel) (26 $\mu \mathrm{g})$ can be kept to select type 
of process and facilite sineresis and retrogradation on corn starch [6-9].

Folic acid, $(2 S)-2-[4-[(2-a m i n o-4-o x o-1 H-p t e r i d i n-6-$ yl) methylamino]benzoyl] mino]pentanedioic acid, N-[4[(2-amino-1,4-dihydro-4-oxo- 6-pteridinyl)methyl] amino] benzoyl]- L-glutamic acid, Pteroylglutamic acid, Vitamin $\mathrm{B}_{9}$, Vitamin $\mathrm{M}$, Folacin $\left(\mathrm{C}_{19} \mathrm{H}_{19} \mathrm{~N}_{7} \mathrm{O}_{6}\right)$ has sensitive properties on sun's light, oxygen, heat and high temperature (particularly boiling) so that to isolate and keep its presence of folic acid in enriched food is important process [10]. Folic acid in enriched food (smart food) is considered as a shape of real food with appropriate nutritional value. It consist of components giving contribution on smart brain, and very important to be consumed before and during early pregnancy to prevent emergence of serious birth defects of the brain (anencephaly) as Neural Tube Defects (NTDs), spine (spina bifida), low-birth-weight baby and malformation in the general population $[11,12]$.<smiles>Nc1nc(O)c2nc(CNc3ccc(C(=O)N[C@@H](CCC(=O)O)C(=O)O)cc3)cnc2n1</smiles>

Fig. 1. Structure of folic acid.

Effect of all processes on status of folic acid and glutamic acid become a reference guide how far folic acid monomer is achieved by Liquid Chromatography-Mass Spectrometry (LC-MS) instrument. Identification on folic acid and glutamic acid through LC-MS instrument is operated to monitor MW-monomer domination according to intensity in order to display nixtamal characteristic. This matter is related to sensitive of folic acid and various shapes and folic acid structure to reach operation condition effect of nixtamalization. By using chromatography, it will be separated a molecular mixture based on difference in migration rate and molecular distribution in stationary phase (adsorben) and mobile phase (eluen), while mass spectrometry will ionize analit according to electro spray ionization (ESI) principle to gas phase (fine aerosol) [13, 14]. The goal of this experimental activity was to find out characteristic of the best nixtamalized yellow dent corn and white dent corn by different time in boiling and concentration of solution of $\mathrm{Ca}(\mathrm{OH})_{2}$, and its identification on folic acid monomer.

\section{Experimental design}

\subsection{Materials and Equipments}

Main materials used in this experimental activity were dry yellow dent corn and dry white dent corn from Tangerang, standard folic acid, standard glutamic acid, all the chemicals used were reagent grade. Process equipments used in this experimental works were nixtamalization process system, grinder (local), sieve of 60 mesh (Retsch, Germany) and Dead-End Stirred Ultrafiltration Cell (SUFC) (Model 8200, Amicon Bioseparation, MILLIPORE, U.S.A.) for preparation analyses of Liquid Chromatography-Mass Spectrometry (LC-MS). While, main analysis instrument was LC-MS. Mariner Biospectrometry) equipped with LC (Hitachi L 6200).

Experimental works were subsequently performed by selecting corn grains, steeping whole corn in solution of $\mathrm{Ca}(\mathrm{OH})_{2}$ with concentrations of $0,10,20,30$ and $40 \%$ (w/w corn dissolved protein) for 18 hours, respectively, followed then by boiling at $90{ }^{\circ} \mathrm{C}$ for $15,30,45$ and 60 minutes, draining, drying and reducing size at room temperature. Analyses were performed on dissolved protein (Lowry method) [15], total solids (Gravimetric method), reducing sugar (Somogyi-Nelson), total sugars (Phenol Sulphate method) [16], folic acid (UV-vis Spectrophotometer) [17]. Identification on folic acid and glutamic acid were conducted by means of LC-MS equipped with LC (Hitachi L 6200) [18]. Process and analysis were conducted in duplicate. Data processed in this description were based on the result of average analysis.

\subsection{Procedure}

\subsubsection{Nixtamalization process}

A corn nixtamalization process consist of washing and steeping in water in a $1: 4$ mixture with water. On raw corn steeping was then added by $\mathrm{Ca}(\mathrm{OH})_{2}$ with concentrations of $0,10,20,30$ and $40 \%$ (w/w corn dissolved protein) for 18 hours of steeping time. For each treatment was performed a boiling at $90{ }^{\circ} \mathrm{C}$ for $0,10,20,30,40,50$, and 60 minutes, cooling overnight, and washing to remove a portion of its skin or the remaining pericarp and excess lime, and draining so that it is produced steeped corn (nixtamal). Steeped corn (nixtamal) was ground into masa, grinded to reduce size, and sieved through a sieve of 60 mesh to produce nixtamalized corn flours for further process.

\subsubsection{Identification of folic acid through LC-MS}

Samples of extract as a result of purification result was conducted by using nixtamal corn from the best process condition through microfiltration (MF) membrane $(0.15$ $\mu \mathrm{m})$ [19], standard folic acid and standard glutamic acid. Analyses of monomers folic acid and glutamic acid were performed by LC-MS instrument. The LC-MS system consisted of an ion trap Mass Spectrometer and a Liquid Chromatography. LC system is integrated with Q-tof Mass Spectrometer by Electro Spray Ionization (ESI), in which scan mode is performed in range of $\mathrm{m} / \mathrm{z} 100-1200$ at 140 ${ }^{\circ} \mathrm{C}$. LC (Hitachi L 6200) uses a C18-18 RP (5 $\mu \mathrm{m}$ particle size, $15 \mathrm{~cm} \times 1 \mathrm{~mm}$ i.d.) column from Supelco (Bellefonte, PA). Type of solvent used ismethanol at a flowrate of $0.1 \mathrm{~mL} / \mathrm{min}$. And injection volume was $2 \mathrm{uL}$ [18]. 


\section{Results and Discussion}

\subsection{Characteristic of corn.}

Selection on dent corns are based on a facility to achieve and prepare them broader when compared to others varieties. Both types of corn show difference in colour, size and uniform of grains, as shown in Figure 2, and composition of dent corns are showed in Table 1. White dent corn displays high concentration of folic acid (211.24 ug/mL) when compared to yellow dent corn $(159.7 \mathrm{ug} / \mathrm{mL})$. This matter is appropriate with higher concentration of dissolved protein $(0.07 \mathrm{mg} / \mathrm{mL})$ than that yellow dent corn $(0.05 \mathrm{mg} / \mathrm{mL})$. It had been known that folic acid (pteroyl-L-Glutamic acid) is a derivative glutamic acids so that it is soluble in water relating with amino acids in general [9].
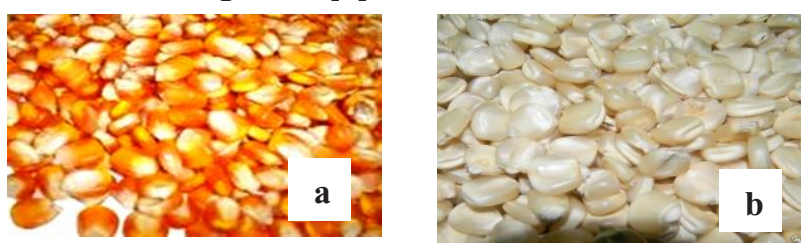

Fig. 2. (a) Yellow dent corn and (b) white dent corn (Zea mays identata).

Meanwhile, sufficient high concentration of corn protein ( $\pm 9 \%$ ), higher when compared to other cereals (rice), however under soys $( \pm 14 \%)$ so that corn protein has potential use as source of protein and energy (carbohydrate). The whole compositions related to types and varietis of corn, particularly flavonoid phenolic pigment, such as beta-caroten, lutein, xanthins and cryptoxanthin pigment with vitamin A in yellow dent corn which do not contained in white dent corn. This matter causes both stronger aroma and taste of yellow dent corn. Different trend is seemed on total sugars, in which white dent corn yields lower content of total sugars (208.38 $\mathrm{mg} / \mathrm{mL})$ compared with yellow dent corn $(310.22 \mathrm{mg} / \mathrm{mL})$, on the other hand, higher content of reducing sugars $(982.16 \mathrm{mg} / \mathrm{mL})$ compared with yellow dent corn $(640.18$ $\mathrm{mg} / \mathrm{mL})$. Total sugars relating with high content of starch $(72 \%)$ is main component in composing corn carbohydrate. This matter is related with types, varieties of corns and post harvesting processes. Reducing sugars are relating with boiling process of corn on difference in boiling time and alkali concentration before and after nixtamalization. Composing simple sugars with reduction property during nixtamalization has a role in bonding folic acid of nixtamalized corn. Similar trend seems at fat concentration, in which yellow dent corn shows higher concentration of fat $(4.65 \%)$ when compared to white dent corn $(3.81 \%)$. Besides, due to variety of corn, this matter is also effected by post harvesting drying processes and fat content in initial material when harvesting. Corn fat is enabled to have an important role in emulsification process through homogenation process under both optimal rotation speed and time prior to drying process performed in order to produce nixtamalized flour with better oil absorber in application products.

Table 1. Composition of yellow dent corn and white dent corn (Zea mays identata)

\begin{tabular}{|c|c|c|c|c|c|c|}
\hline \multirow[b]{2}{*}{$\begin{array}{l}\text { Kind of dent } \\
\text { corn }\end{array}$} & \multicolumn{6}{|c|}{ Component } \\
\hline & $\begin{array}{c}\text { Folic acid } \\
(\mu \mathrm{g} / \mathrm{mL})\end{array}$ & $\begin{array}{c}\text { Total solid } \\
\text { (\%) }\end{array}$ & $\begin{array}{c}\text { Dissolved } \\
\text { protein } \\
(\mathrm{mg} / \mathrm{mL})\end{array}$ & $\begin{array}{c}\text { Total sugar } \\
(\mu \mathrm{g} / \mathrm{mL})\end{array}$ & $\begin{array}{c}\text { Reducing } \\
\text { sugar }(\mathrm{mg} / \mathrm{mL})\end{array}$ & Fat (\%) \\
\hline Yellow & 87.52 & 159.70 & 0.05 & 310.22 & 12.30 & 4.65 \\
\hline White & 93.86 & 211.24 & 0.07 & 208.38 & 9.95 & 3.81 \\
\hline
\end{tabular}

\subsection{Effect of nixtamalization process on composition}

Nixtamalization process is conducted by adding solution of $\mathrm{Ca}(\mathrm{OH})_{2}$ of $0,10,20$ and $30 \%$ (w/w, dissolved protein of corn) on yellow dent corn and white dent corn, and boiling for 15, 30, 45 and 60 minutes, respectively.

\subsubsection{Folic acid}

Nixtamalization process on yellow dent corn increases folic acid until ability level of binding (20\%) followed by dropping folic acid for all boiling time, as showed Figure 3. Optimization of folic acid was achieved at solution of $\mathrm{Ca}(\mathrm{OH})_{2} 20 \%$ (w/w corn dissolved protein) for 60 minutes boiling and gave $466.81 \mathrm{ug} / \mathrm{mL}$. Compared with folic acid of initial material (159.70 $\mathrm{ug} / \mathrm{mL}$ ), the optimal process condition increases folic acid from $159.70 \mathrm{ug} / \mathrm{mL}$ to $466.81 \mathrm{ug} / \mathrm{mL}$ (192.3\% or 1.9 times). This increase of folic acid is caused by its occurrence of starch gelatinization on corn seed link. In same time, solution of $\mathrm{Ca}(\mathrm{OH})_{2}$ will be absorbed causing its linked components, such as folic acid. While, decrease of folic acid is possibility caused by excess in solution of $\mathrm{Ca}(\mathrm{OH})_{2}$ so that it is occurred coagulation of protein and lysis on further processes (filtration, cooling, draining, reducing size). Properties of folic acid (pteroyl-Lglutamic acid) is dissolved in water [9] coagulated by alkali or $\mathrm{Ca}(\mathrm{OH})_{2}$ solution and sensitive on light, oxigent, high temperature and process treatments using pressure $[20,21]$.

Different trend seems on white dent corn, in which increase of folic acid is still running to the highest concentration of $\mathrm{Ca}(\mathrm{OH})_{2}$ solution $(30 \%)$, although is fluctuating, as displayed in Figure 4. To achieve the optimal folic acid, nixtamalization rate demonstrated at higher concentration of $\mathrm{Ca}(\mathrm{OH})_{2}$ solution will need shorter cooking time. In other words, adding $\mathrm{Ca}(\mathrm{OH})_{2}$ solution enables to strengthen corn starch gel by binding amylose chain during boiling process causing stronger 
structure of corn starch, in which folic acid will be binded strong at starch gel at same time. It had been known that corn has high content amylose of $28 \%$ and amylopectin of $72 \%$, so that they are easy to fulfil sineresis and retrogradation [22]. Optimization of folic acid at nixtamalized white dent corn is obtained at $\mathrm{Ca}(\mathrm{OH})_{2}$ solution of $30 \%$ for 30 minutes of boiling with result of $506.74 \mathrm{ug} / \mathrm{mL}$. Compared with folic acid in initial material of white dent corn $(211.24 \mathrm{ug} / \mathrm{mL})$, the optimum process condition raises folic acid from $211.24 \mathrm{ug} / \mathrm{mL}$ to $506.74 \mathrm{ug} / \mathrm{mL}$ (139.89 \% or 1.4 times). While, decrease of folic acid is possibility caused by excess in solution of $\mathrm{Ca}(\mathrm{OH})_{2}$ so that it is occurred coagulation of protein and lysis on further processes (filtration, cooling, draining, reducing size). Properties of folic acid (pteroyl-Lglutamic acid) is dissolved in water (Belitz, et al, 2009) coagulated by alkali or $\mathrm{Ca}(\mathrm{OH})_{2}$ solution and sensitive on light, oxigent, high temperature and process treatments using pressure $[20,21]$. Different trend seems on white dent corn, in which increase of folic acid is still running to the highest concentration of $\mathrm{Ca}(\mathrm{OH})_{2}$ solution $(30 \%)$, although is fluctuating, as displayed in Figure 4.

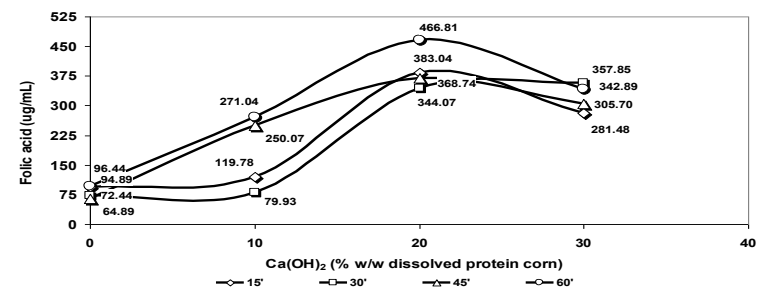

Fig. 3. Relationship between $\mathrm{Ca}(\mathrm{OH})_{2}$ concentration and boiling time at $90{ }^{\circ} \mathrm{C}$ on folic acid in nixtamalized yellow dent corn.

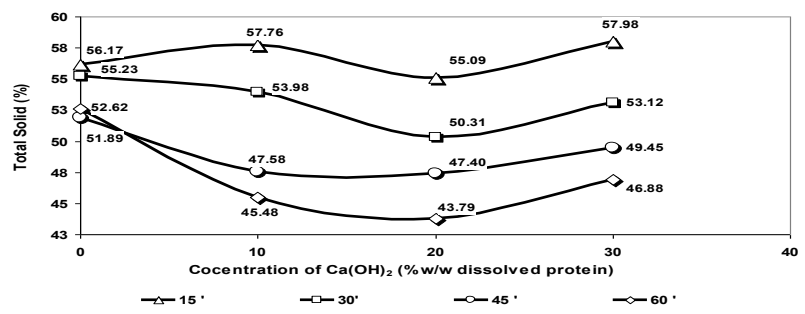

Fig. 4. Relationship between $\mathrm{Ca}(\mathrm{OH})_{2}$ concentration and boiling time at $90{ }^{\circ} \mathrm{C}$ on folic acid in nixtamalized white dent corn.

To achieve the optimal folic acid, nixtamalization rate demonstrated at higher concentration of $\mathrm{Ca}(\mathrm{OH})_{2}$ solution will need shorter cooking time. In other words, adding $\mathrm{Ca}(\mathrm{OH})_{2}$ solution enables to strengthen corn starch gel by binding amylose chain during boiling process causing stronger structure of corn starch, in which folic acid will be binded strong at starch gel at same time. It had been known that corn has high content amylose of $28 \%$ and amylopectin of $72 \%$, so that they are easy to fulfil sineresis and retrogradation [22]. Optimization of folic acid at nixtamalized white dent corn is obtained at result of $506.74 \mathrm{ug} / \mathrm{mL}$. Compared with folic acid in Compared with folic acid in initial material of white dent corn $(211.24 \mathrm{ug} / \mathrm{mL})$, the optimum process condition raises folic acid from $211.24 \mathrm{ug} / \mathrm{mL}$ to $506.74 \mathrm{ug} / \mathrm{mL}(139.89 \%$ or1.4times $)$.

\subsubsection{Total solids}

Total solids is an accumulation for the whole components in nixtamalized corn both soluble and insoluble extracted according to Gravimetric method [16]. Nixtamalization process on yellow dent corn gave fluctuated total solids and was tend to drop, as demonstrated in Figure 5. Dropping total solids was possiblity caused by its occurrence of water mass adsorption at net of corn grains causing swelling starch gel to decrease total solids. Optimization of total solids reached at treatment of $\mathrm{Ca}(\mathrm{OH})_{2}$ solution of $30 \%(\mathrm{w} / \mathrm{w}$ corn soluble protein) for 15 minutes of boiling gave $57.98 \%$. Compared with initial material of corn $(87.52$ $\%)$, the optimum process condition declined total solids to $57.98 \%(33.75 \%)$.

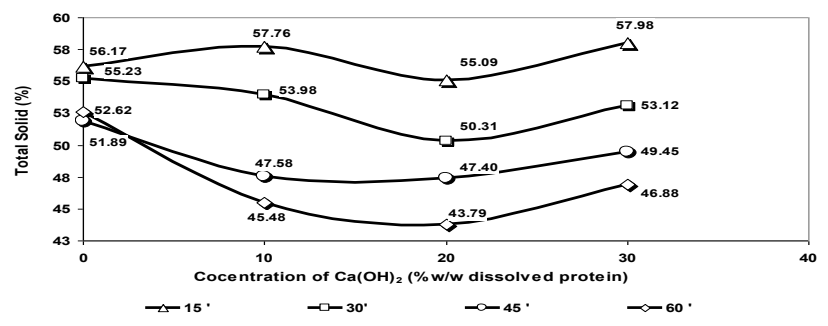

Fig. 5. Relationship between $\mathrm{Ca}(\mathrm{OH})_{2}$ concentration and boiling time at $90{ }^{\circ} \mathrm{C}$ on recovery of total solids in nixtamalized yellow dent corn.

Different trend seemed at nixtamalized white dent corn, in which raising total solids is occurred at treatment of $\mathrm{Ca}(\mathrm{OH})_{2}$ solution of $10 \%$ (w/w corn soluble protein) and almost all boiling time followed by decreasing fluctuation relating with increasing $\mathrm{Ca}(\mathrm{OH})_{2}$ concentration, as showed in Figure 6.

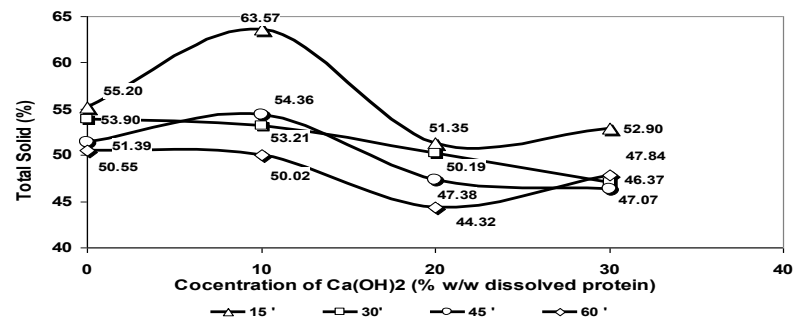

Fig. 6. Relationship between $\mathrm{Ca}(\mathrm{OH})_{2}$ concentration and boiling time at $90^{\circ} \mathrm{C}$ on recovery of total solids in nixtamalized white dent corn.

Optimization of total solids $(63.57 \%)$ was achieved at treatment combination of $\mathrm{Ca}(\mathrm{OH})_{2}$ solution of $10 \%$ for 15 minutes of boiling, and became more and more low relating with increasing $\mathrm{Ca}(\mathrm{OH})_{2}$ solution concentration. When compared to total solids of initial corn material $(93.86 \%)$, the optimum process condition dropped total solids from $93.86 \%$ to $63.57 \%(32.37 \%)$. This matter displayed that niztamalization rate was tend to lower total solids relating with long cooking time, although adding solution of $\mathrm{Ca}(\mathrm{OH})_{2}$ became more and more much amount. Excess in concentration of $\mathrm{Ca}(\mathrm{OH})_{2}$ solution of $10 \%(\mathrm{w} / \mathrm{w}$ corn soluble protein), boiling process system was not able to retain gelatinization in order to dissolve components of corn, so that is dropped total solids. 


\subsubsection{Dissolved protein}

Dissolved protein of nixtamalized corn is all amino acids, peptides, and protein derivative, which is soluble in water and is binded by other components as a result of nixtamalization process. Dissolved protein of nixtamalized corn becomes a main process reference guide because of folic acid. Folic acid is protein derivative owning chemical structure of combination from pteridin heterocyclic, para-aminobenzoat acid (PABA) and pteroyl-L-glutamic acid. Its presence of high protein of corn $(7-10 \%)$ becomes reference guide to select this cereals, besides high content of folic acid $(26 \mu \mathrm{g})$ and its potential use as source of energy [9]. Nixtamalization process on yellow dent corn gave optimization $(0.038 \mathrm{mg} / \mathrm{mL})$ achieved at treatment combination of concentration of $\mathrm{Ca}(\mathrm{OH})_{2}$ of $10 \%(\mathrm{w} / \mathrm{w}$ corn dissolved protein) and boiling time of 15 minutes, as displayed in Figure 7.

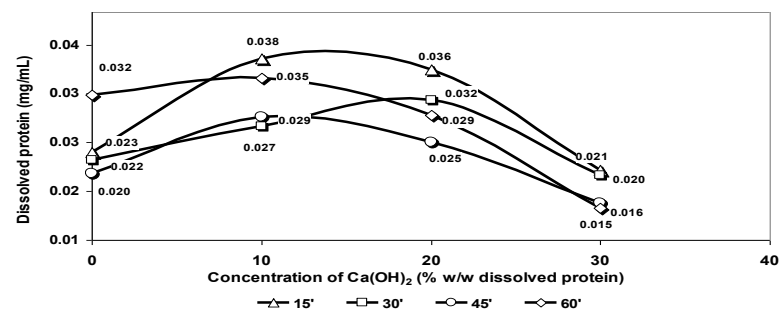

Fig. 7. Relationship between $\mathrm{Ca}(\mathrm{OH})_{2}$ concentration and boiling time at $90{ }^{\circ} \mathrm{C}$ on recovery of dissolved protein in nixtamalized yellow dent corn.

Compared with dissolved protein of initial corn material, the optimum process condition lowered dissolved protein from $0.05 \mathrm{mg} / \mathrm{mL}$ to $0.038 \mathrm{mg} / \mathrm{mL}$ (24\% or 0.24 times). Simultaneously decrease of dissolved protein is taken place at concentration $\mathrm{Ca}(\mathrm{OH})_{2}$ solution of $30 \%(\mathrm{w} / \mathrm{w}$ corn dissolved protein $)$. This matter is possibility caused by coagulation to bind $\mathrm{Ca}(\mathrm{OH})_{2}$ solution, in which long boiling time will become more and more low dissolved protein. This matter seems for the longest boiling time (60 minutes). Other possibilities were caused by processes relating with after boiling process, such as homogenization $(8000$ $\mathrm{rpm}, 30$ minutes) or size reducing. Similar trend seemed at nixtamalized white dent corn, in which rate of nixtamalization reaction was fluctuative and was tend to raise relating with high concentration of $\mathrm{Ca}(\mathrm{OH})_{2}$ solution. Increasing is reverse proportional with boiling time, in which boiling time becoming more and more long will drop dissolved protein, as demonstrated in Figure 8.

Optimization process was achieved at concentration of $\mathrm{Ca}(\mathrm{OH})_{2}$ solution of $30 \%(\mathrm{w} / \mathrm{w}$ corn dissolved protein) for 15 minutes of boiling time and gave soluble protein $0.041 \mathrm{mg} / \mathrm{mL}$ followed by lowering $(0.033$ $\mathrm{mg} / \mathrm{mL}$ ) relating with long boiling time for 60 minutes. When compared to dissolved protein of initial white dent corn material $(0.07 \mathrm{mg} / \mathrm{mL})$, the optimum process condition drops dissolved protein from $0.07 \mathrm{mg} / \mathrm{mL}$ to $0.041 \mathrm{mg} / \mathrm{mL}$ ( $41.43 \%$ or 0.41 times).

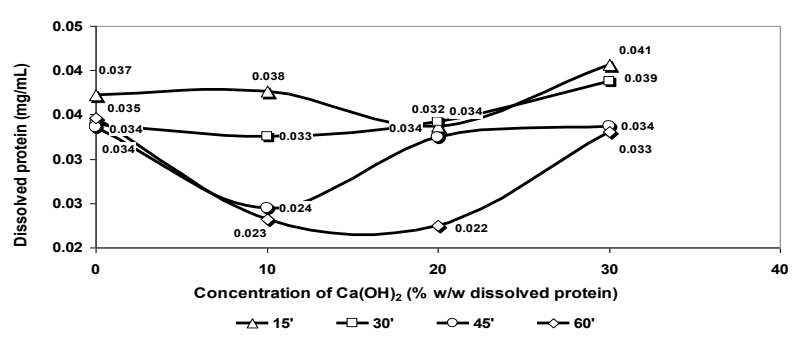

Fig. 8. Relationship between $\mathrm{Ca}(\mathrm{OH})_{2}$ concentration and boiling time at $90{ }^{\circ} \mathrm{C}$ on recovery of dissolved protein in nixtamalized white dent corn.

\subsubsection{Total sugar}

Total sugars on nixtamalized corn is a guidelines from all carbohydrates according to Phenol - Sulphate metode [16]. In boiling process of corn $\left(90^{\circ} \mathrm{C}\right)$, it is happened fractionation of amylose (27\%) and amylopectin (72\%) contained in corn to form gel at corn granular net and dissolve glucose expressed as total sugars. Treatment on yellow dent corn showed fluctuated nixtamalization process rate relating with increase of solution of $\mathrm{Ca}(\mathrm{OH})_{2}$. Treatment of boiling time of 15 minutes raises total sugars until maximum concentration of $\mathrm{Ca}(\mathrm{OH})_{2}$ ( $20 \% \mathrm{w} / \mathrm{w}$ corn dissolved protein) to produce higher concentration of total sugar when compared to all treatments followed by dropping to maximum concentration of $\mathrm{Ca}(\mathrm{OH})_{2}(30 \% \mathrm{w} / \mathrm{w}$ corn dissolved protein). In other processes displays an increase of total sugars, although maximum concentration of $\mathrm{Ca}(\mathrm{OH})_{2}$ $(30 \% \mathrm{w} / \mathrm{w}$ corn dissolved protein) and boiling time longer than 15 minutes, as shown in Figure 9.

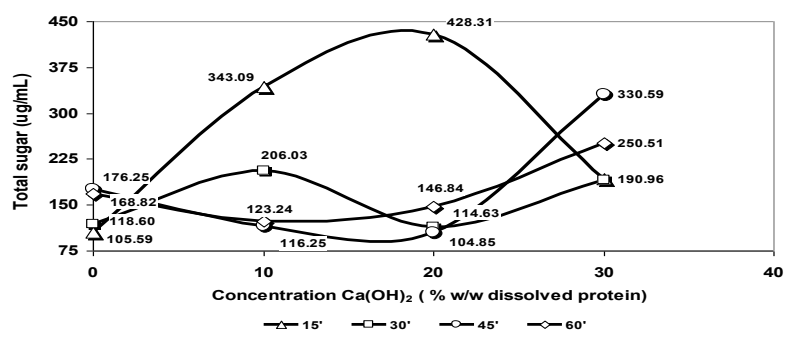

Fig. 9. Relationship between $\mathrm{Ca}(\mathrm{OH})_{2}$ concentration and boiling time at $90{ }^{\circ} \mathrm{C}$ on recovery of total sugars in nixtamalized yellow dent corn.

Optimization process was achieved by adding solution of $\mathrm{Ca}(\mathrm{OH})_{2}$ of $20 \%$ (w/w corn dissolved protein) for 15 minutes of boiling and gave total sugars concentration of $428.31 \mathrm{ug} / \mathrm{mL}$. In this condition, it showed an increase of total sugars concentration from $428.31 \mathrm{ug} / \mathrm{mL}$ to $310.22 \mathrm{ug} / \mathrm{mL}$ (initial material of yellow dent corn $38.07 \%$ (0.38 times). Whereas, white dent corn demonstrated a different trend of reaction rate, in which declining total sugars is taken place simultaneously at all process treatments, as showed in Figure 10. 


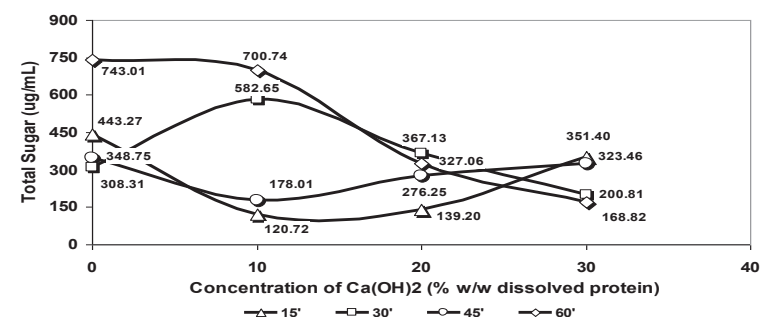

Fig. 10. Relationship between $\mathrm{Ca}(\mathrm{OH})_{2}$ concentration and boiling time at $90{ }^{\circ} \mathrm{C}$ on recovery of total sugars in nixtamalized white dent corn.

Process optimization was obtained without adding solution of $\mathrm{Ca}(\mathrm{OH})_{2}$ for 60 minutes of boiling and gave total sugars of $743.01 \mathrm{ug} / \mathrm{mL}$. When compared to total sugars of initial corn material, optimum process condition increased total sugars from $208.38 \mathrm{ug} / \mathrm{mL}$ to $743.01 \mathrm{ug} / \mathrm{mL}$ ( $256.56 \%$ or 2.56 times). This matter is possibility occurred autohydrolysis on corn granules netting like heat reaction on polysaccharides 208.38 $\mathrm{ug} / \mathrm{mL}$ become $743.01 \mathrm{ug} / \mathrm{mL}$.

\subsubsection{Reducing sugar}

Reducing sugar at nixtamalized corn is parameter used to degrade polysaccharides (starch) of corn through both heat reaction and natural enzymatic by bacteria during steeping process in water and boiling with or without adding solution of $\mathrm{Ca}(\mathrm{OH})_{2}$. These processes are enabled to form reducing sugars, such as glucose and fructose according to Nelson-Somogyi method [16]. High content of amylose and amylopectin in corn causes retrogradation and syneresis easily. Adding solution of $\mathrm{Ca}(\mathrm{OH})_{2}$ enables non-reactive fractionation process so that formation of monosaccharide with reduction property can be controlled. Nixtamalization process of yellow dent corn and white dent corn demonstrates a similar pattern, in which process rate displayes an fluctuated increase of reducing sugars relating with raising solution of $\mathrm{Ca}(\mathrm{OH})_{2}$, however it is reverse proportional with boiling time. In other words, high concentration of $\mathrm{Ca}(\mathrm{OH})_{2}$ solution and short boiling time will increase reducing sugar, as displayed in Figures 11 and 12.

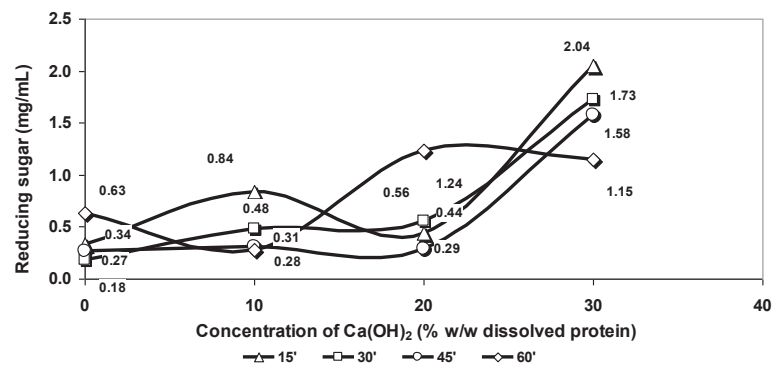

Fig. 11. Relationship between $\mathrm{Ca}(\mathrm{OH})_{2}$ concentration and boiling time at $90{ }^{\circ} \mathrm{C}$ on recovery of reducing sugar in nixtamalized yellow dent corn.

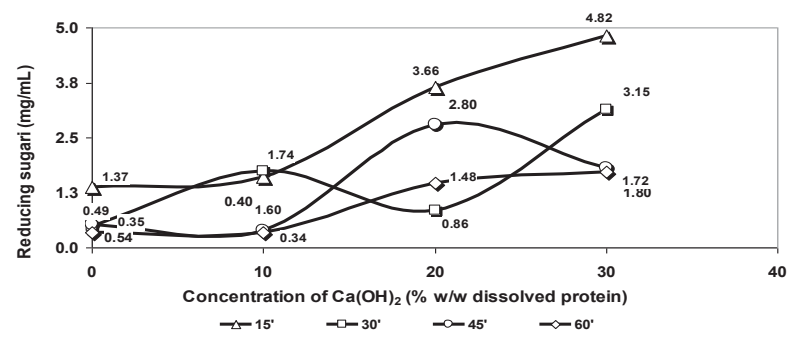

Fig. 12. Relationship between $\mathrm{Ca}(\mathrm{OH})_{2}$ concentration and boiling time at $90{ }^{\circ} \mathrm{C}$ on recovery of reducing sugar in nixtamalized white dent corn.

Optimization of both nixtamalized yellow dent corn and white dent corn were achieved at concentration of $\mathrm{Ca}(\mathrm{OH})_{2}$ of $30 \%$ (w/w corn protein) for 15 minutes yielded reducing sugars of $2.04 \mathrm{mg} / \mathrm{mL}$ and $4.82 \mathrm{mg} / \mathrm{mL}$, respectively. Compared with both reducing sugars of initial material of yellow dent corn $(12.30 \mathrm{mg} / \mathrm{mL})$ and white dent corn $(9.95 \mathrm{mg} / \mathrm{mL})$, optimum process condition declined reducing sugars of $83.41 \%$ and $51.56 \%$, respectively. This matter showed that solution of $\mathrm{Ca}(\mathrm{OH})_{2}$ will increase starch gelatinization. On the other hand, at similar period, heat effect with long boiling time will retain gelatinization in order to drop reducing sugars.

From description above, it had been known that based on the highest concentration of folic acid both yellow dent corn and white dent corn, optimization of nixtamalization process were achieved at treatment combination of concentration of $\mathrm{Ca}(\mathrm{OH})_{2}$ solution of 20 $\%$ (w/w corn dissolved protein) for 60 minutes of boiling time and concentration of $\mathrm{Ca}(\mathrm{OH})_{2}$ solution of $30 \%$ (w/w corn dissolved protein) for 30 minutes of boiling time, and gave nixtamalized corn with folic acid concentration of $466.80 \mathrm{ug} / \mathrm{mL}$ and $506.74 \mathrm{ug} / \mathrm{mL}$, as shown in Figures 13a and 13b.
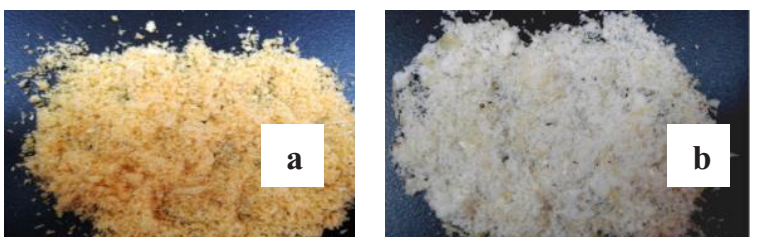

Fig. 13. (a) Nixtamalized yellow dent corn and (b) nixtamalized white dent corn at optimum process condition.

\subsection{Identification of folic acid and glutamic acid monomer in nixtamalized corn}

Identification on monomer of nixtamalized corn was performed on folic acid and glutamic acid as a part of folic acid. Identification result on standard glutamic acid was achieved 1 peak (T3.0) at retention time of $0-10$ minutes with relative intensity of $100 \%$, in which in mass spectra $m / z 111$ - 784 from T3.0 showed domination of compounds with molecular weight (MW) of 148.1479 Da. (100\%), as shown in Figures 14 and 15. 


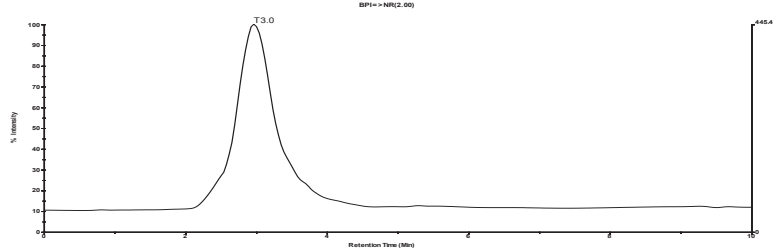

Fig. 14. Chromatogram of standard glutamic acid with retention time (T)3.0.

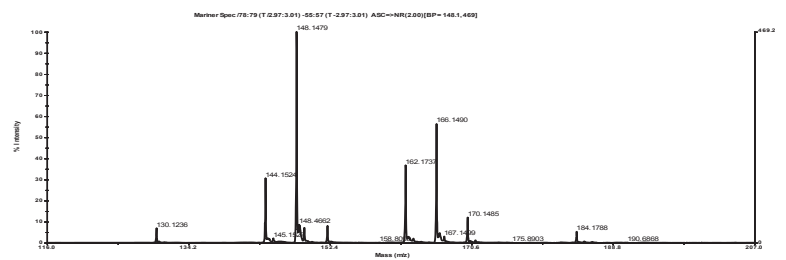

Fig. 15. Mass spectra in T 3.0 at $\mathrm{m} / z 128-207$ at standard glutamic acid.

Folic acid is combination between pteridin heterocyclic, para-aminobenzoate acid (PABA) and glutamic acid [9]. In standard folic acid was reached 1 peak (T1.7) at retention time of $0-10$ minutes with relative intensity of $100 \%$, in which in mass spectra $\mathrm{m} / \mathrm{z}$ 425 - 498 from T1.8 displayed domination of compounds with MW of 442.76 Da. (100\%), 443.7 (25 $\%)$, and 441.48 (5\%), as showed in Figures 16 and 17.

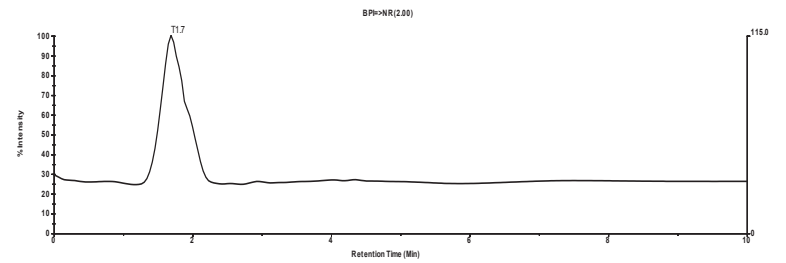

Fig. 16. Chromatogram of standard folic acid with retention time (T)3.0.

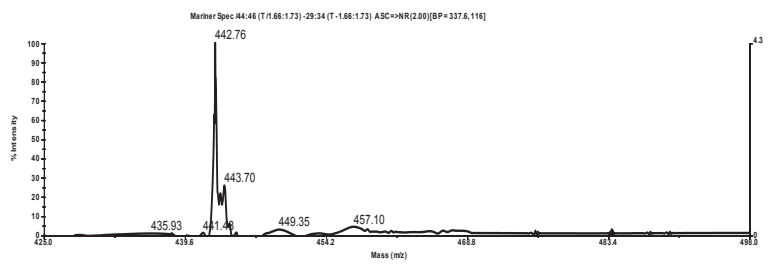

Fig. 17. Mass spectra in $\mathrm{T} 3.0$ at $\mathrm{m} / \mathrm{z} 425-498$ at standard folic acid.

Folic acid has MW of $441 \mathrm{Da}$. [9], however, due to LC-MS system (type of solvent, injection concentration, flow rate), it enables to degrade folic acid [18]. By using LC-MS method had been known that a compound indicated difference in MW, in which its possibility is as $\mathrm{M}^{+}, \mathrm{M}^{+} \mathrm{Na}^{+}, 2 \mathrm{M}^{++}$or $2 \mathrm{M}^{+}, \mathrm{Na}^{+}$. This matter is caused by its presence of ionization as a consequence of sensitivity of LC-MS instrument relating to eluent used.

\subsubsection{Nixtamalized yellow dent corn}

Identification result on the best treatment of nixtamalized yellow dent corn (boiling time of 60 minutes, concentration of $\mathrm{Ca}(\mathrm{OH})_{2}$ solution of $20 \%$ (w/w corn dissolved protein) was obtained chromatogram with 1 peak $(\mathrm{T} 1.5)$ at retention time 0 10 minutes, as displayed in Figure 18.

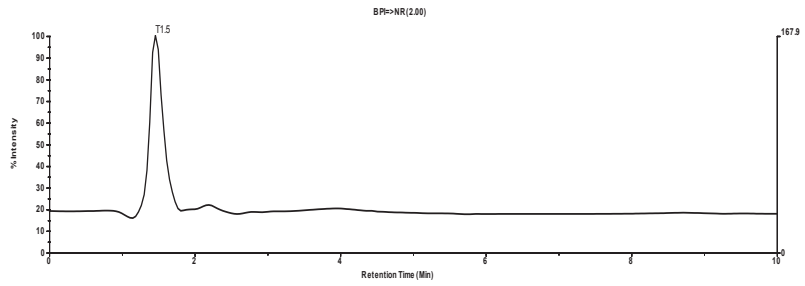

Fig. 18. Chromatogram of nixtamalized yellow dent corn from optimum process condition with retention time $0-10$ minutes (T) 1.5 .

In mass spectra from T1.39 ranging $m / z 99-1200$ (Figure 19) did not shows glutamic acid monomer, although it had been known that relative intensity of glutamic acid was $1.41 \%$, while at this mass spectra range did not resulted folic acid. Glutamic acid monomer has been monitored at mass spectra ranging $\mathrm{m} / \mathrm{z} 147.43$ - 149 with MW between 147.94 - 148.93 Da. and relative intensity from 1.18 to $0.81 \%$. This mass spectra was dominated by monomer with MW of $148.27 \mathrm{Da}$. and relative intensity of $3.73 \%$, as demonstrated in Figure 20. Similar matter seemed on folic acid monomer, in which at mass spectra ranging $\mathrm{m} / z \quad 440 \quad-443$ demonstrates folic acid monomer with MW ranging $441.02-443.51 \mathrm{Da}$. and relative intensity of $4.93-$ $11.82 \%$. This mass spectra was dominated by monomer with MW of $442.56 \mathrm{Da}$. and relative intensity of $25.51 \%$, as shown in Figure 21.

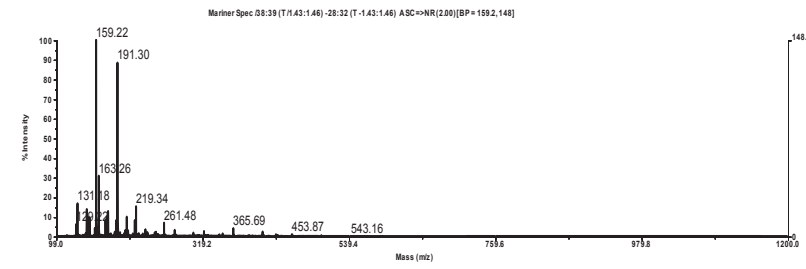

Fig. 19. Mass spectra of nixtamalized yellow dent corn from optimum process condition ranging $m / z 99-1200$.

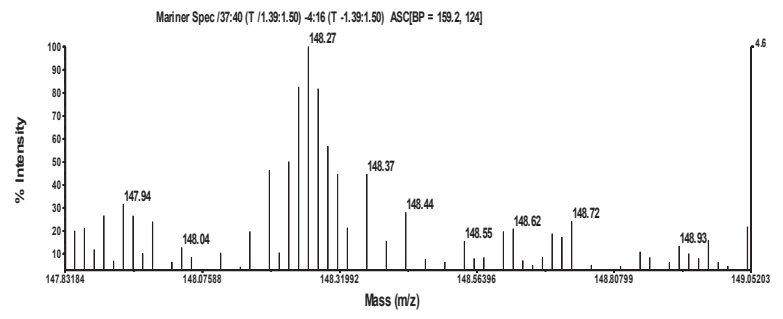

Fig. 20. Glutamic acid monomer in nixtamalized yellow dent corn from optimum process condition at mass spectra ranging $m / z 147.43-149$ in $\mathrm{T} 1,5$. 


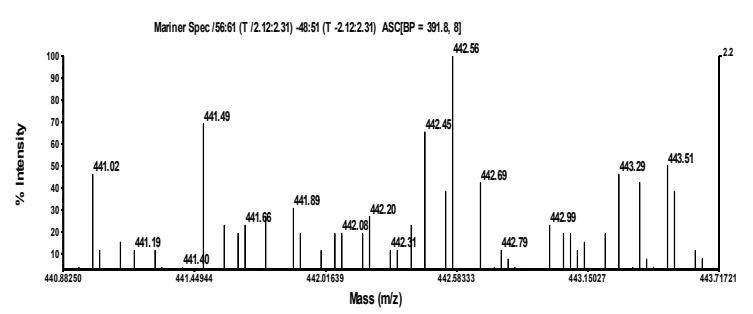

Fig. 21. Folic acid monomer in nixtamalized yellow dent corn from optimum process condition at mass spectra ranging $\mathrm{m} / \mathrm{z}$ $440-443$ in $\mathrm{T} 1,5$.

\subsubsection{Nixtamalized white dent corn}

Identification result on nixtamalized white dent corn from the best treatments (boiling of 30 minutes, concentration of $\mathrm{Ca}(\mathrm{OH}) 2$ solution of $30 \%$ (w/w corn dissolved protein) was achieved chromatogram with 1 peak (T1.5) at retention time of $0-10$ minutes, as shown in Figure 22. Mass spectra from T1.5 ranging $\mathrm{m} / \mathrm{z} 99-$ 1200 (Figure 23) did not demonstrate glutamic acid monomer, although it is monitored clearly at mass spectra ranging $m / z 147.39$ - 148.96 with MW ranging $147.92-148.86 \mathrm{Da}$. and relative intensity from 0.71 to $1.8 \%$. This mass spectra was dominated by MW of $148.32 \mathrm{Da}$. and relative intensiy of $1.8 \%$, as showed in Figure 24. Folic acid monomer with MW of 441.94 Da. was reached with relative intensity of $0.12 \%$ at ranging $m / z 99-1200$ (Figure 23), however at mass spectra ranging $\mathrm{m} / \mathrm{z} 440.81-443.38$ with $\mathrm{MW}$ of $440.92-$ 443.23 Da., and relative intensity from $0.43-2.29 \%$ displayed clearer.

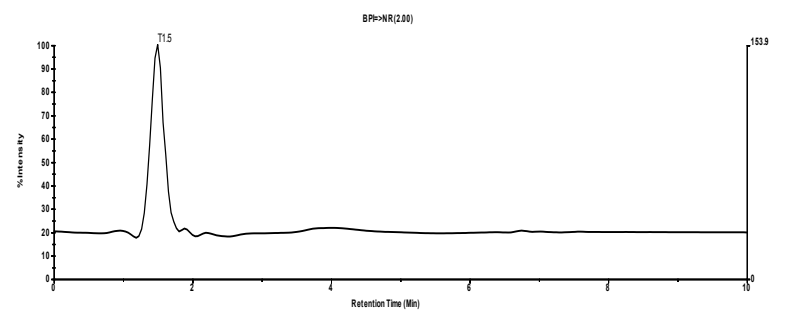

Fig. 22. Chromatogram of nixtamalized white dent corn from optimum process condition with retention time $0-10$ minutes (T)1.5.

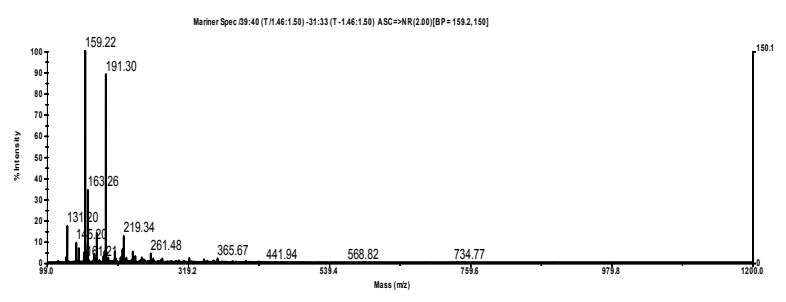

Fig. 23. Mass spectra of nixtamalized white dent corn from optimum process condition ranging $m / z 99-1200$.

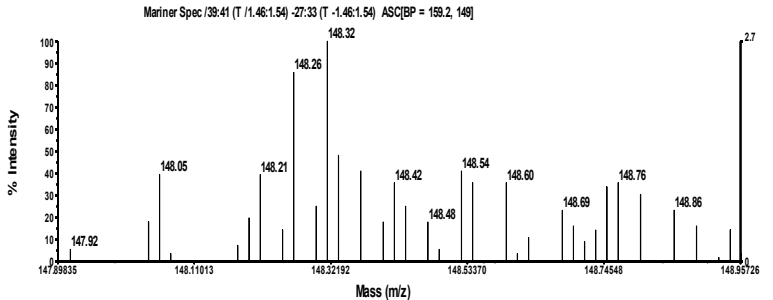

Fig. 24. Glutamic acid monomer at mass spectra ranging $\mathrm{m} / \mathrm{z}$ 147.39 - 148.96 in T1,5 nixtamalized white dent corn from optimum process condition .

This mass spectra was dominated by a monomer with MW 441.73 Da. and relative intensity of $100 \%$, as displayed in Figure 25. On these whole identifications had showed that boiling $\left(90^{\circ} \mathrm{C}\right)$ and further processes (boiling, reducing size) remains still folic acid and glutamic acid by bonding of $\mathrm{Ca}(\mathrm{OH})_{2}$ on nixtamal. Glutamic acid is combination between pteridin heterocylic, para-aminobenzoat (PABA) and glutamic acid [9].

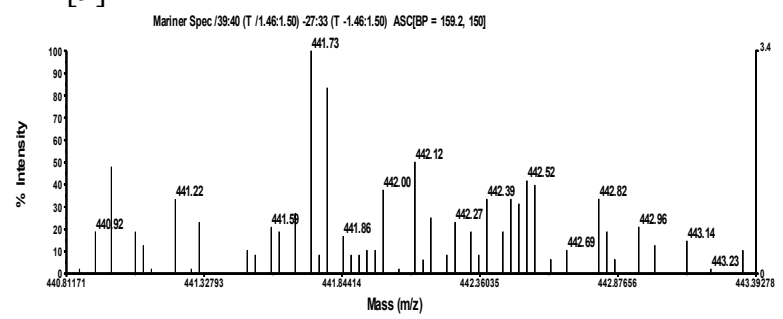

Fig. 25. Folic acid monomer in nixtamalized white dent corn from optimum process condition at mass spectra $\mathrm{m} / z 440.81$ 443.38 in $\mathrm{T} 1,5$.

\section{Conclusions}

Nixtamalization process with difference concentration of solution of $\mathrm{Ca}(\mathrm{OH})_{2}$ and boiling time of corn affected on the overall nixtamalization compositions. $\mathrm{Ca}(\mathrm{OH})_{2}$ solution concentration becoming more and more high increases concentrations of folic acid and reducing sugar, declines total solids and total sugars, and tends to fluctuate and drop dissolved protein both two types of corn. Based on the highest folic acid, optimization of nixtamalization treatments at yellow dent corn and white dent corn were achieved at combination between concentration $\mathrm{Ca}(\mathrm{OH}) 2$ solution of $20 \%$ (w/w corn dissolved protein) for 60 minutes of boiling and concentration $\mathrm{Ca}(\mathrm{OH}) 2$ solution of $30 \%$ (w/w corn dissolved protein) for 30 minutes of boiling. In these optimum conditions, it is produced both nixtamalized flours of yellow dent corn and white dent corn with compositions of folic acid of 466.81 and $506.74 \mu \mathrm{g} / \mathrm{mL}$, total solids of 43.78 and $47.06 \%$, dissolved protein of 0.029 and $0.039 \mathrm{mg} / \mathrm{mL}$, total sugars of 146.840 and $200.809 \mathrm{ug} / \mathrm{mL}$, and reducing sugar of 1.236 and 3.151 $\mathrm{mg} / \mathrm{mL}$, respectively, and give an increase on folic acid $192.3 \%$ (1.9 folds) and $139.89 \%$ (1.4 folds) compared with initial materials of yellow dent corn and white dent corn. Identification on folic acid and glutamic acid monomers in both nixtamalized yellow dent corn and nixtamalized white dent corn at optimum operation 
condition demonstrated domination of folic acid monomer of MW of 442.56 and $441.73 \mathrm{Da}$. with relative intensity of 25.51 and $100 \%$, respectively. While, glutamic acid monomer in both nixtamalized yellow dent corn and nixtamalized white dent corn were dominated by monomers with MW of 148.27 and 148.32 Da., and relative intensities of 3.73 and $1.8 \%$, respectively.

\section{References}

1. Anonymous. Recommendations for the use of folic acid to reduce the number of cases of spina bifida and other neural tube defects. MMWR Recomm. Rep., 41 (No. RR.14) (1992).

2. De Wals, P., Rusen, I. D., Lee, N. S., Morin, P., and Niyonsenga, T. Trend in prevalence of neural tube defects in Quebec. Birth Defects Res A Clin Mol Teratol., 67, p.919- 23 (2003).

3. Anonymous. EUROCAT. Special Report : Prevention of Neural Tube Defects by Periconceptional Folic Acid Supplementation

4. Wronkowska, M. Wet-Milling of Cereals, Journal of Food Processing and Preservation ISSN 1745-4549, 40, p.572 - 580. doi:10.1111/jfpp.12626 (2016).

5. Rooney, L.W. and Serna-Salvidar, S.O. Food uses whole corn and dry milled factions. in Corn : Chemistry and Technology (Watson, S. A. and Ramsted, P. E., ed.). ACCC. St. Paul, M. N. (1987), F. (ed.), Molecular Structure and Function or Food Carbohydrate. Appl. Sci. Publ. Ltd., London (1973).

6. Argun, M. S. and Dogan, I. S. Effects of varying nixtamalization conditions on the calcium absorption and pasting properties of dent and flint corn flours, Journal of Food Process Engineering, ISSN 1745-4530, 40 : e12436. Wiley Periodicals, Inc., p.1 - 7. doi:10.1111/jfpe.12436 (2017).

7. Banks, W., Greenwood, C. T. and Muir, D. D. The Structure of Starch in Birch, G. G. and Green, L

8. Nilsen, R. M., Leoncini, E., Gastaldi, P., Allegri, V., Agostino, R., Faravelli, F., Ferrazzoli, F., Finale, E., Ghirri, P., Scarano, G., and Mastroiacovo, P. Prevalence and determinants of preconception folic acid use : an Italian multicenter survey, Italian Journal of Pediatrics, Published online July 13, 42 : 65, p. 1 - 10. DOI 10.1186/s13052-016-0278-z. Open Access. CrossMark (2016).

9. Belitz, H. D., Grosch, W., and Schieberle, P. Food Chemistry. $4^{\text {th }}$ revised and extended edition, Springer-Verlag, Berlin Heidelberg. ISBN 3-54015043-9 (2009).

10. Anonymous. Folic acid, Semolus. Accessed at 8 December 2014 (2008).

11. Anonymous. FDA approves folic acid fortification of corn masa flour, U. S. Food and Drug Administration News Release, April 14 (2016).
12. Hamner, H. C. and Tinker, S. C. Fortification of corn masa flour with folic acid in the United States: an overview of the evidence, ANNALS OF THE NEW YORK ACADEMY OF SCIENCES. ISSN 0077 8923. 1312, p. 8 - 14. New York Academy of Sciences (2014).

13. Onggo, D. General Principles in Electrospray Mass Spectrometry : A New Technique in Mass Spectral Analysis. Journal of Mass Spectrum, Vol. 3, No. 2, pp.115 - 131, Wikipedia. Accessed at 3 February 2013 (1998).

14. Dass, Chreh. Dasar-dasar Spektrometri Massa Kontemporer. John Wiley \& Sons, Inc., pp.151 194. doi : 10.1002/9780470118498.ch5. ISBN 9780470118498. Accessed at 20 April 2017 (2007).

15. Lowry, O. H., Rosebrough, N. J., Farr, A. L., Randall, R. J. Protein measurement with Folin phenol reagent. J. Biol. Chem. 193 (1), pp.265-276. PMID 14907713 (1951).

16. AOAC. Official Methods of Analysis. Association of Official Analytical Chemists International, 20th. Edition, Washington D. C. (2016).

17. Ruengsitagoon, W. and Hattanat, N. Simple spectrophotometric method for determination of folic acid. The $4^{\text {th }}$ Annual Northeast Pharmacy Research Conference, Thailand (2012).

18. Eichhorn, P. and Knepper, T. P. Electrospray ionization mass spectrometric studies on the amphoteric surfactant cocamidopropylbetaine. Journal of Mass Spectrum, June : 36 (6), pp.677 684. DOI : 10.1002/jms. 170 (2001).

19. Susilowati, A., Iskandar, Y. M., Melanie, H., Maryati, Y., Lotulung, P. D., Aryani, D. G. Pengembangan konsentrat sayuran hijau dan kacang-kacangan terfermentasi pada jagung (Zea mays L.) pramasak sebagai sumber asam folat untuk formula pangan pintar. Laporan Hasil Penelitian, Program Tematik, Kedeputian IPT, Tahun Anggaran 2015, Pusat Penelitian Kimia - LIPI, Kawasan PUSPIPTEK, Serpong, Tangerang Selatan (2015).

20. Verlinde, P., Oey, I., Deborggraeve, W., Me, J., Hendrickx, M. E., Van Loey, A. M. Mechanism and related kinetics of 5-methyltetrahydrofolic acid degradation during combined high hydrostatic pressure-thermal treatments. Journal of Agricultural and Food Chemistry, 57 (15) : 6803 14. Accessed at 25 April 2017 (2009).

21. Delchier, N., Ringling, C., Maingonnat, J. F., Rychlik, M., Renard, C. M. G. C. Mechanisms of folate losses during processing: diffusion vs heat degradation. Food Chem., 157: pp.439 - 47. Accessed at 25 April 2017 (2014).

22. Fleche, G. Chemical Modification and Degradation of Starch in G.MA. Van Beynum and J. A. Rolls (eds.), Marcel Dekker Inc., New York, U. S. A. (1985). 